\title{
Visual prey availability and distribution of foraging little auks (Alle alle) in the shelf waters of West Spitsbergen
}

\author{
Lech Stempniewicz $\cdot$ Mirosław Darecki $\cdot$ Emilia Trudnowska $\cdot$ Katarzyna Błachowiak-Samołyk \\ Rafał Boehnke • Dariusz Jakubas · Liliana Keslinka-Nawrot • Dorota Kidawa • \\ Sławomir Sagan · Katarzyna Wojczulanis-Jakubas
}

Received: 15 October 2012/Revised: 15 March 2013/Accepted: 28 March 2013/Published online: 12 April 2013

(C) The Author(s) 2013. This article is published with open access at Springerlink.com

\begin{abstract}
As diving seabirds use vision underwater, it is presumed they should preferentially select sites where their preferred food items are not only abundant but also clearly visible. To test this, we studied the optical properties of the seawater in the West Spitsbergen Shelf, in combination with zooplankton abundance in the feeding grounds of the planktivorous little auks from the nearby colonies in Hornsund. We estimated the relative attractiveness of the foraging sites using a novel parameter-visual prey availability $(V P A v)$, which relates density and proportion of the preferred food item (Calanus glacialis) of the little auk, in total zooplankton, to the optical properties of the seawater. We found a significant positive correlation between the density of foraging little auks and VPAv values. Birds chose areas where $C$. glacialis was both abundant and clearly visible, because of the clarity of the water and low proportion of other zooplankton species. The birds avoided foraging over the warmer Atlantic-type waters, characterised by a high abundance of zooplankton taxa mostly ignored by birds and where $V P A v$ values were low. $V P A v$ values could potentially also be applied to other visual planktivores for which prey preference and visual acuity are known.
\end{abstract}

L. Stempniewicz $(\bowtie) \cdot$ D. Jakubas · L. Keslinka-Nawrot .

D. Kidawa $\cdot$ K. Wojczulanis-Jakubas

Department of Vertebrate Ecology and Zoology, University of

Gdańsk, ul. Wita Stwosza 59, 80-308 Gdańsk, Poland

e-mail: biols@univ.gda.pl; biols@ug.edu.pl

M. Darecki - E. Trudnowska · K. Błachowiak-Samołyk ·

R. Boehnke $\cdot$ S. Sagan

Institute of Oceanology, Polish Academy of Sciences, ul.

Powstańców Warszawy 55, 81-712 Sopot, Poland
Keywords Water transparency $\cdot$ Zooplankton accessibility $\cdot$ Foraging $\cdot$ Little auks $\cdot$ Spitsbergen

\section{Introduction}

Marine food webs are influenced by light through its effect on photosynthesis, productivity and vertical distributions of both phyto- and zooplankton. The optical properties of the seawater are also crucial in regulating the visual foraging efficiency of visually hunting aquatic animals including seabirds. Visual range and resolution are poorer underwater than on land, and this limits the distance over which potential prey can be detected and makes feeding more difficult (Martin and Prince 2001). Water transparency is determined mainly by the amount of suspended inorganic and organic particles, including phytoplankton, and is of importance to diving seabirds, since an increase in turbidity reduces their visual acuity (Eriksson 1985; Aksnes and Giske 1993; Kuroki et al. 2003; Henkel 2006). The optical properties of water and the abundance and vertical distribution of prey in the feeding grounds influence diving behaviour and foraging efficiency of different groups of seabirds, depending on the hunting technique they use (Ainley 1977). However, previous studies have generally considered water transparency as one of many factors that individually influences seabird underwater foraging. For instance, Day et al. (2003) found that foraging areas of closely related and sympatrically occurring marbled (Brachyramphus marmoratus) and Kittlitz's (B. brevirostris) murrelets differed mainly in water clarity. Plungedivers, such as terns, might benefit from feeding over turbid water, because the small fishes that constitute their prey move closer to the well-lit surface waters, where in turn, the phytoplankton tends to concentrate (Haney and Stone 
1988; Baptist and Leopold 2010). The contrast degradation theory predicts that high turbidity not only decreases the visibility of objects, but also increases the minimum size of particles that can be detected (Lythgoe 1979; De Robertis et al. 2003). According to this hypothesis, an increase in turbidity hinders the detection of zooplankton aggregations by visual-feeding planktivorous seabirds, both from the air and from underwater.

The little auk (Alle alle) is a planktivorous seabird, considered a keystone species in the Arctic ecosystem owing to its huge population and amphibious way of life during the breeding season (Stempniewicz 1990, 2001). It is believed that the little auk has the highest metabolic rate of all seabirds, due to its small size (ca. $150 \mathrm{~g}$ ) and high costs of flying and swimming underwater (Konarzewski et al. 1993; Harding et al. 2009). To cover such extreme energy demands, it focuses on Arctic-originated zooplankton (Kwasniewski et al. 2010), as such items are much more profitable and energy-rich than their Atlantic water counterparts (Weslawski et al. 1999). For instance, in the shelf waters of West Spitsbergen, Calanus glacialis associated with Arctic water masses is preferred by little auks over its much less energy-rich $C$. finmarchicus that originates from Atlantic waters, (Karnovsky et al. 2003). For this reason, little auks are expected to respond obviously and rapidly to any changes in distribution of the water masses and related zooplankton communities. Indeed, little auks that breed in the vicinity of waters under the influence of the warm Atlantic current appear to forage in suboptimal conditions and this increases their foraging effort and affects breeding success (Jakubas et al. 2007; Karnovsky et al. 2010; Jakubas et al. 2011; Harding et al. 2011).

Even though the performance of little auk foraging appears to be crucial to understanding their responses to the potential, climate-related changes in oceanographic conditions, relatively little is known concerning the birds' behaviour at sea and their underwater foraging. A few studies indicate that the birds' diving behaviour (i.e. depth and duration) might be affected by the oceanographic conditions (Harding et al. 2009; Karnovsky et al. 2011). Recently, Kwasniewski et al. (2010) showed that little auks foraging in two different water regimes (feeding grounds predominated by Arctic vs. Atlantic waters) faced a similar abundance of the preferred zooplankton items, but in smaller proportions in relation to other zooplankters in the Atlantic-type water masses. In consequence, the birds presumably spent more time foraging in the Atlantic waters. This study clearly suggests that foraging performance of the little auk might be determined not only by prey quality and abundance per se, but might also be related to the birds' capability to perceive, distinguish and select their prey. All these raise concern, apparently neglected in studies so far, concerning underwater visibility and little auk foraging efficiency in various water masses.
In this study, we aimed to investigate whether the availability of $C$. glacialis to little auks was affected by optical properties of the water in the foraging grounds. We performed the study in the Hornsund area, one of the largest breeding aggregations of the little auk, in Spitsbergen. This is also the area where two different water masses meet, the Arctic and Atlantic, forming divergent oceanographic environments in the vicinity of little auk colonies. As larger phytoplankton blooms and zooplankton assemblages containing a higher fraction of the smaller zooplankton species are characteristic for warm Atlantic domains compared to Arctic ones (Mann and Lazier 2006; Kwasniewski et al. 2010), we expected that the availability of $C$. glacialis differs in these two water masses.

\section{Materials and methods}

\section{Study areas and field work}

We performed the study on the shelf of West Spitsbergen, in the sea area adjacent to a large little auk colony in Hornsund fjord, which had previously been studied as a little auk feeding ground (Karnovsky et al. 2003, 2010; Jakubas et al. 2011). The Hornsund area is influenced by two current systems: firstly, the coastal Sørkapp Current, which advects in cold, low salinity water from the northeast Barents Sea, and secondly, the West Spitsbergen Current, which advects in warmer and more saline water originating from the Norwegian Sea (Fig. 1). The meeting of these two water masses creates a frontal zone of differing range in particular seasons (Daase et al. 2007; Walczowski and Piechura 2007). We performed measurements of the hydrology and optical characteristics in conjunction with zooplankton sampling and little auk censuses. We conducted sampling and measurements during surveys of the West Spitsbergen Shelf aboard IO PAS (Institute of Oceanology Polish Academy of Sciences) RV "Oceania" at a semi-fixed grid of stations on the shelf adjacent to the colony in Hornsund (Fig. 1). As the sampling location followed the IO PAS long-term monitoring programme described in detail in several previous papers (e.g. Karnovsky et al. 2003; Kwasniewski et al. 2010, 2012), only the most relevant information is included in this paper. The number and positions of stations differed between the two investigated years, depending on weather conditions. All data were collected concurrently between 25 and 28 July 2009 (15 stations) and 2010 (21 stations) (Fig. 1).

Hydrological and optical measurements

We took measurements with an Integrated OpticalHydrological Probe (IOHP), consisting of a SBE 49 


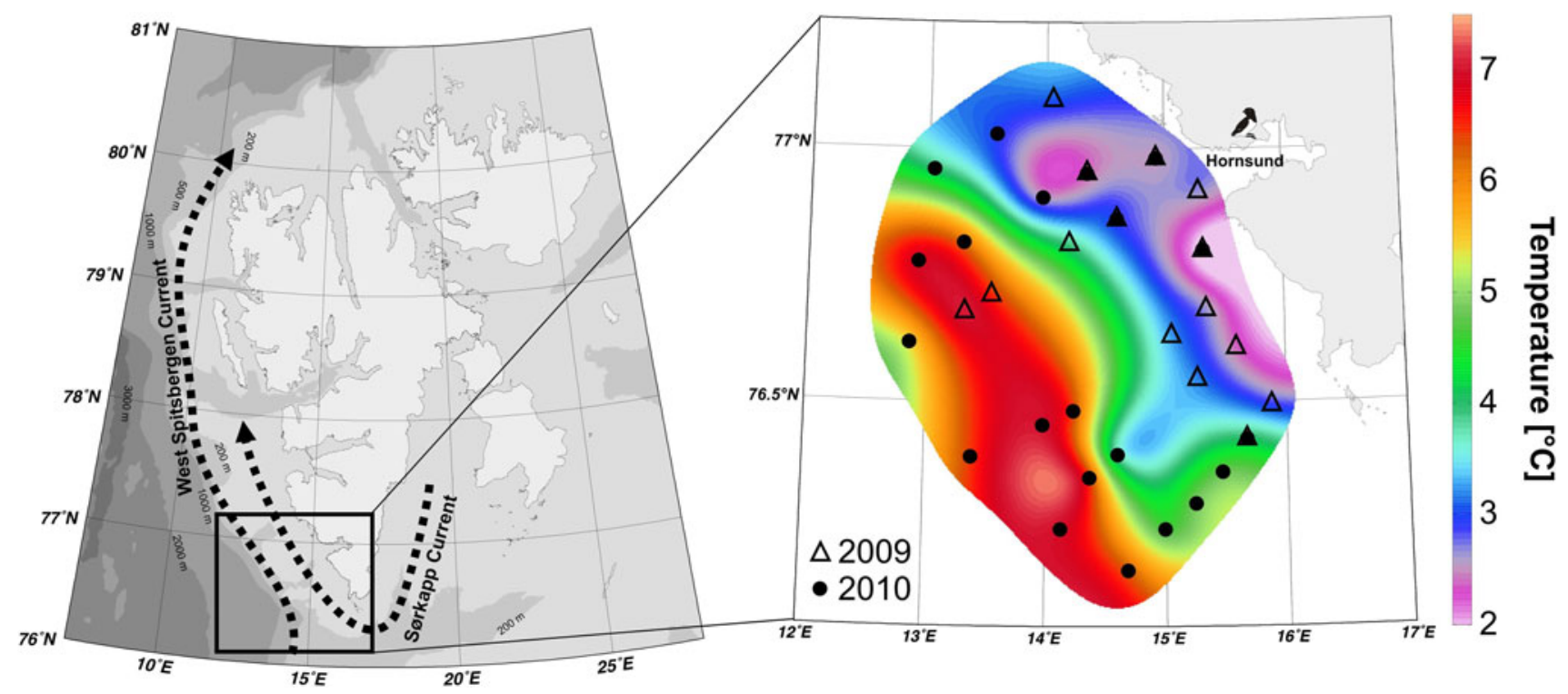

Fig. 1 West Spitsbergen Shelf and study area in the vicinity of Hornsund fjord with sampling stations on the hydrological background. Arrows show schematic current system; sampling stations (triangle 2009; circle 2010); little auk icon—breeding colony location

FastCat CTD probe (Sea-Bird Electronics) ac-9 underwater spectrophotometer (WET Labs) and CDOM fluorometer (TriOS). Measurements of the light absorption $a$ and attenuation $c$ with ac-9 were taken at nine wavelengths from 412 to $715 \mathrm{~nm}$. The instrument was calibrated in pure water and routinely checked for stability with air-readings. Corrections for temperature, salinity and scattering were applied (Zaneveld et al. 1994). IOHP recordings (profiles) of temperature, salinity, and optical properties were collected concurrently in the upper $50 \mathrm{~m}$ of the water column.

We used measurements of the beam attenuation coefficient $c(1 / \mathrm{m})$ at $555 \mathrm{~nm}$ to assess the underwater visibility (Vis), assuming that the water is as usual, most transparent in this sector of the light spectrum [the underwater visibility range for the human eye can be adequately described as 4.8/c555 (m)] (Zaneveld and Pegau 2003). Data on the visual acuity of other pursuit-diving birds are scarce, that is, the visual acuity of the cormorant (Phalacrocorax carbo) is equivalent to that of the unaided human underwater (White et al. 2007). Therefore, we used the c555 inverse value ( $1 / \mathrm{c} 555)$ as a proxy for a relative comparison of the underwater visibility range at the different sites. The beam attenuation data were collected with $30-\mathrm{cm}$ vertical resolution and were averaged vertically every $1 \mathrm{~m}$.

\section{Zooplankton sampling and laboratory work}

We described the composition, abundance and distribution of zooplankton in the little auk feeding grounds based on samples collected at each of the stations adjacent to Hornsund fjord (Fig. 1). We used a WP-2 net with $0.25 \mathrm{~m}^{2}$ opening area, fitted with a filtering gauze of $500 \mu \mathrm{m}$ mesh size. The net was hauled vertically from the depth of $50 \mathrm{~m}$ to the surface, and the zooplankton sample was preserved in $4 \%$ formaldehyde in seawater, buffered with borax.

Each zooplankton sample was first scanned for larger $(>0.5 \mathrm{~cm})$ zooplankters, which were extracted, identified and counted. The remaining part of the sample was examined for species composition and abundance by dividing the material into subsamples. The number of subsamples was determined individually in order to count at least 300 individuals per sample. All organisms in each $2-\mathrm{mL}$ volume subsample were identified and enumerated (Harris et al. 2000). Calanus were identified to the species level, and the developmental stage (copepodid) was based on the descriptions given in Kwasniewski et al. (2003). Since older C. glacialis copepodit stages CIV and CV constitute the bulk of the diet fed to little auk chicks in the Hornsund area (Kwasniewski et al. 2012), in this paper, we used the term $C$. glacialis with respect to these two stages combined.

\section{Little auk at-sea surveys}

We conducted ornithological surveys during the RV "Oceania" cruises in the study area adjacent to Hornsund fiord. Observers carried out the surveys whenever the vessel was underway and counted the number of little auks observed in a $90^{\circ}$ arc from the front of the vessel to the side (a distance up to $\sim 300 \mathrm{~m}$ ), at the best visibility (Karnovsky et al. 2010). Birds on the water and also those flying low over the sea (e.g. frightened by the vessel or changing foraging sites) were taken into account. Birds passing the study area high in the air were excluded. The density of foraging birds (number of birds per $\mathrm{km}^{2}$ ) was 
calculated along 3-km segments of the transect lines, and the values were assigned to the closest sampling station (Fig. 1).

\section{Data analysis}

To define the parameters that we expected to be related to the availability of zooplankton in the little auk feeding grounds, we assumed that the volume of the water visually 'scanned' by each little auk is proportional to the distance of underwater visibility (Vis) to the third power (considering three-dimensional zooplankton distribution in the water and the stereoscopic vision of diving birds; Martin and Prince 2001). Based on this assumption, the potential number of zooplankters visible to a diving bird is calculated as the volume of the water visible to the bird multiplied by concentration of the zooplankton in that volume. We devised an index, the 'visual prey availability' (VPAv), which relates to the 'visual' availability of the food items preferred by little auks, that is, C. glacialis. Thus, VPAv is proportional to the number of $C$. glacialis individuals potentially available to a diving little auk, multiplied by the ratio of the Prey Abundance $(P A b)$ to the Total Zooplankton Abundance $(T Z A b)$ in the sample. Where $C$. glacialis is the most abundant zooplankter, VPAv is high. However, when its abundance and/or concentration compared to that of other zooplankters is very low, VPAv values are close to zero. Moreover, when prey abundances are similar, little auks are able to see more food items when the water is clearer (higher $V P A v$ ) then when it is turbid, which reduces the total volume of water in which the prey can be detected and the VPAv value is thus relatively small.

Visual prey availability was defined by the following equation:

$V P A v=\left(P A b * V i s^{3}\right) * \frac{P A b}{T Z A b}$

where $P A b=$ prey abundance $=$ number of $C$. glacialis in $1 \mathrm{~m}^{3}$ of the water sample; TZAb = total zooplankton abundance $=$ number of total zooplankton items in $1 \mathrm{~m}^{3}$ of the water sample; $V i s=1 / \mathrm{c} 555$ parameter proportional to the distance of underwater visibility, where $c 555=$ the beam attenuation coefficient at $555 \mathrm{~nm}$.

Although the present index is a relative parameter, it combines two factors that affect prey availability, that is zooplankton density and its visibility. Hence, we considered that this parameter enables comparisons of the relative attractiveness of different foraging grounds for planktivores.

Because the investigated variables did not meet the assumptions of parametric tests and were generally autocorrelated (all $r_{s}>0.33, P<0.05$ except for underwater visibility), we performed nonparametric procedures: Spearman rank correlations coefficients and Kruskal-
Wallis and Mann-Whitney tests ( $U$ test, if $N<30$ and $Z$ test, if $N>30$ ). Data were presented as median values (Me) with Q1-Q3 as the 25-75\% quartile range. Data collected at particular sampling stations during the two seasons studied were used as independent variable sets.

Since three types of water masses distinguished on the basis of hydrology and zooplankton communities were earlier described in the Hornsund study area (Walczowski and Piechura 2007; Jakubas et al. 2011; Kwasniewski et al. 2012), we also used this categorisation of the water masses.

We computed all statistical tests in STATISTICA 8.0 and illustrated the visual prey availability using DIVA interpolation in Ocean Data View software.

\section{Results}

Little auks foraged at nine of the thirty-six (25\%) sampling stations. The sampling stations at which little auks were foraging differed markedly from those where no birds were recorded. The differences were apparent in the VPAv indices, with much higher values where the birds were foraging. Also, the proportion of the preferred Arctic copepod, C. glacialis, was higher, and the underwater visibility was better at the stations where birds were present, compared to those stations with no recorded birds. Moreover, the water at stations with birds was characterised by lower salinities, lower temperatures and lower total zooplankton abundances (Table 1) compared to the stations with no birds. Stations at which foraging little auks were most abundant ( $>100$ birds $\mathrm{km}^{-2}$; Fig. 2) were characterised by a low sea surface temperature $\left(\mathrm{Me}=2.9, \mathrm{Q}_{1}-\mathrm{Q}_{3}=\right.$ 2.3-3.1), low sea surface salinity $\left(\mathrm{Me}=33.6, \mathrm{Q}_{1}-\right.$ $\left.\mathrm{Q}_{3}=33.3-34.1\right)$, high proportions of $C$. glacialis $(\mathrm{Me}=$ 35.7, $\left.\mathrm{Q}_{1}-\mathrm{Q}_{3}=19.0-48.3\right)$ and very high $V P A v$ indices $\left(V P A v, \mathrm{Me}=694, \mathrm{Q}_{1}-\mathrm{Q}_{3}=162-6,407\right)$.

The density of little auks foraging at each sampling station correlated positively with the visual availability of C. glacialis (VPAv; $r_{s}=0.74, P<0.001$; Fig. 2). Also, the relative proportions of $C$. glacialis in the zooplankton samples correlated positively with the number of birds observed foraging $\left(r_{s}=0.68, P<0.001\right)$. Conversely, negative relationships were found between the number of foraging birds and water salinity $\left(r_{s}=-0.68, P<0.001\right)$, temperature $\left(r_{s}=-0.57, P<0.001\right)$ and total zooplankton abundance $\left(T Z A b ; r_{s}=-0.51, P=0.002\right)$.

The birds were recorded mostly in areas predominated by Arctic-type waters that showed highest VPAv values $\left(\mathrm{Me}=950.5 ; \quad \mathrm{Q}_{1}-\mathrm{Q}_{3}=274.6-2,035.5\right)$. Stations influenced by Atlantic-type water were generally avoided by foraging birds (VPAv, $\left.\mathrm{Me}=0.09 ; \mathrm{Q}_{1}-\mathrm{Q}_{3}=0.02-0.30\right)$ (Table 2). 
Table 1 Comparison of the sampling stations occupied (1) and unoccupied (0) by foraging little auks during the at-sea surveys in respect of hydrology, underwater visibility, zooplankton abundance and visual prey availability in the Hornsund study area

\begin{tabular}{|c|c|c|c|c|c|c|}
\hline Parameters & $M e(0)$ & $Q 1-Q 3$ & $M e(1)$ & $Q 1-Q 3$ & $U$ test & $N_{0} / N_{1}$ \\
\hline Temperature $\left({ }^{\circ} \mathrm{C}\right)$ & 4.92 & $4.2-6.7$ & 2.99 & $2.4-4.0$ & $-2.30 *$ & $35 / 11$ \\
\hline Salinity & 34.79 & $34.6-35.1$ & 34.02 & $33.6-34.5$ & $-3.28 * *$ & $35 / 11$ \\
\hline Underwater visibility c555 (m) & 1.93 & $1.4-2.3$ & 2.24 & $2.0-2.8$ & $2.14 *$ & $27 / 9$ \\
\hline Total zooplankton abundance $T Z A b\left(\mathrm{ind} / \mathrm{m}^{3}\right)$ & $4,528.8$ & $2,228-4,749$ & 855.2 & $405.0-1,401.4$ & $-3.85 * *$ & $27 / 9$ \\
\hline Proportion of C. glacialis (\%) & 0.24 & $0.1-3.0$ & 15.0 & 1.9-392 & $3.32 * *$ & $35 / 11$ \\
\hline Abundance of other Calanus (ind $/ \mathrm{m}^{3}$ ) & $4,001.0$ & $2,164.4-4,470.1$ & 567.2 & $229.9-1,148.8$ & $-3.91 * *$ & $27 / 9$ \\
\hline Visual prey availability $V P A v$ (ind) & 0.10 & $0.03-10.1$ & 264.9 & $6.1-984.2$ & $3.31 * *$ & $27 / 9$ \\
\hline
\end{tabular}

Mann-Whitney $U$ test; Me median, Q1-Q3 = 25-75\% quartile range; $N_{0} / N_{1}$-number of stations unoccupied and occupied by little auks; data from 2009 to 2010 combined

$* P<0.05 ; * * P<0.001$
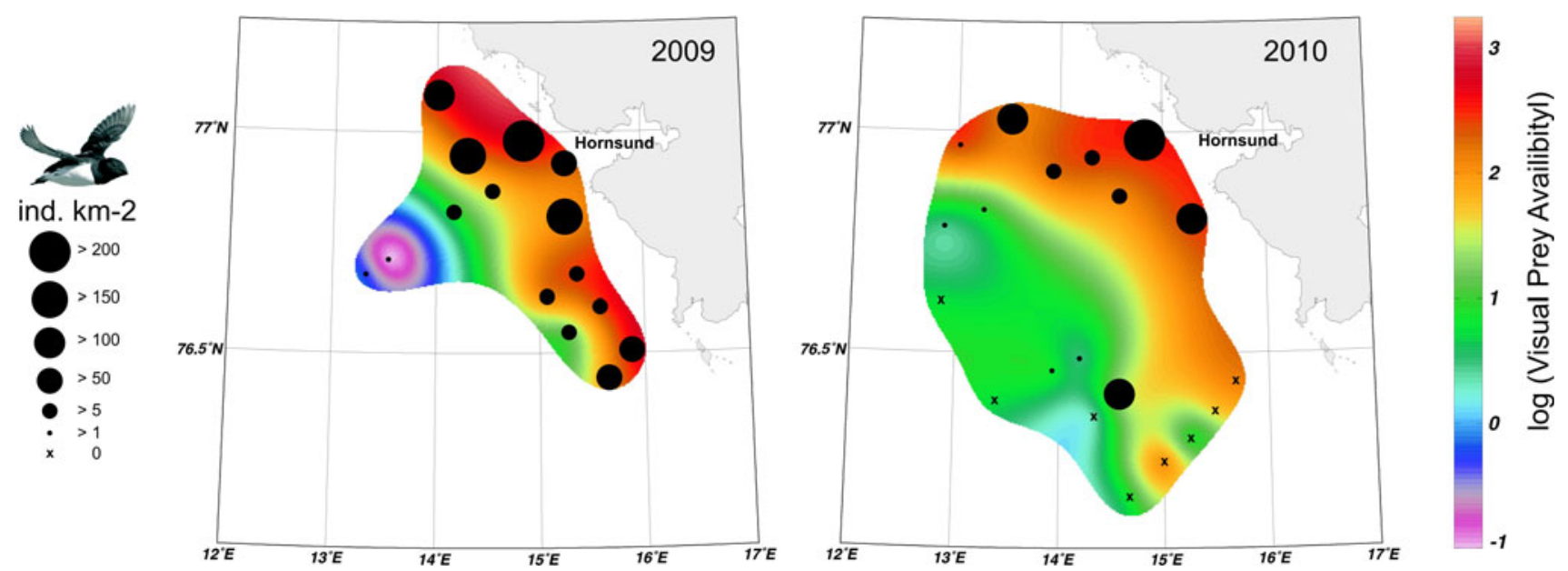

Fig. 2 Distribution of visual availability of $C$. glacialis values ( $\log V P A v$ data) and little auk densities observed at particular sampling stations in the Hornsund area in 2009 and 2010. Circle size reflects little auk density

Table 2 Hydrological, optical and biological characteristics of the three types of water masses, Arctic (ArW), Transitional (TrW) and Atlantic (AtW), distinguished in the Hornsund study area

\begin{tabular}{|c|c|c|c|c|c|c|c|c|c|}
\hline \multirow[t]{2}{*}{ Parameters } & \multicolumn{3}{|c|}{ Arctic (ArW) } & \multicolumn{3}{|c|}{ Transitional (TrW) } & \multicolumn{3}{|c|}{ Atlantic (AtW) } \\
\hline & $M e$ & $Q 1-Q 3$ & $N$ & $M e$ & $Q 1-Q 3$ & $N$ & $M e$ & $Q 1-Q 3$ & $N$ \\
\hline Temperature $\left({ }^{\circ} \mathrm{C}\right)$ & $2.8^{\mathrm{c}}$ & $2.5-3.2$ & 15 & $4.0^{\mathrm{c}}$ & $2.7-4.6$ & 8 & $6.8^{\mathrm{a}, \mathrm{b}}$ & $6.5-7.0$ & 12 \\
\hline Salinity & $33.7^{\mathrm{b}, \mathrm{c}}$ & $33.4-34.0$ & 15 & $34.5^{\mathrm{a}}$ & $34.4-34.7$ & 8 & $35.1^{\mathrm{a}}$ & $35.0-35.1$ & 12 \\
\hline Underwater visibility c555 (m) & 2.3 & $1.9-2.9$ & 15 & 2.0 & $1.4-2.2$ & 8 & 2.3 & $2.0-2.8$ & 12 \\
\hline$T Z A\left(\right.$ ind $\left./ \mathrm{m}^{3}\right)$ & $708.0^{\mathrm{b}, \mathrm{c}}$ & $361.0-915.3$ & 15 & $2,077.8^{\mathrm{a}}$ & $1,441.9-2,835.1$ & 8 & $1,987.3^{\mathrm{a}}$ & $929.6-5,094.2$ & 12 \\
\hline$V P A v$ (ind) & $950.5^{\mathrm{c}}$ & $274.6-2,035.5$ & 15 & 48.0 & $10.8-166.3$ & 8 & $0.09^{\mathrm{a}}$ & $0.02-0.3$ & 12 \\
\hline Little auk density (ind $/ \mathrm{km}^{2}$ ) & $54.0^{\mathrm{b}, \mathrm{c}}$ & $31-176$ & 15 & $1.5^{\mathrm{a}}$ & $0.0-38.0$ & 8 & $1.0^{\mathrm{a}}$ & $0.0-1.6$ & 12 \\
\hline
\end{tabular}

Me median, Q1-Q3 = 25-75\% quartile range; data from 2009 to 2010 combined

a, b, c indicate significant differences (Kruskal-Wallis test, $P<0.05$ ) between the types of water masses: 1 -ArW, 2-TrW, 3-AtW

\section{Discussion}

The favoured foraging sites of the little auks were concentrated in areas of cold waters, with low total zooplankton abundance $(T Z A b)$, composed of very high proportions of $C$. glacialis and the highest visual prey availability $(V P A v)$. The birds distinctly avoided areas of Atlantic and Transitional types of water masses, where $T Z A b$ was high, with a low proportion of $C$. glacialis and low $V P A v$ values. The $V P A v$ values used here appear to be 
a good predictor of little auk foraging areas. We believe that the values could also be applied to other visual planktivores for which prey preferences and visual acuity are known.

Breeding little auks operate as central-place foragers for which foraging time and distance are constrained by the need to repeatedly return to the colony. To maximise foraging efficiency and the rate of feeding chicks, they must be able to detect the optimum foraging sites within a limited distance from the colony. Foraging strategies used by colonially nesting waterbirds include following successful individuals (Ward and Zahavi 1973) and a compass behaviour expressed by rafting birds that indicates the location of the food patches (Weimerskirch et al. 2010). Moreover, birds might be attracted to high-density prey aggregations by other planktivores gathering in the vicinity. It is very likely that little auks also use such a strategy. However, with highly variable sea current systems (Daase et al. 2007), foraging conditions of little auks can change significantly within quite short time periods. Thus, it seems plausible that the birds also use optical cues to verify/ search for appropriate foraging sites. Nevertheless, when food patches are already localised, underwater light conditions have little effect on ingestion rates of food items collected from zooplankton swarms (Lovvorn 2010).

At the beginning of their foraging trips, little auks usually land on the sea relatively close to the colony and apparently sample potential feeding sites by flying short distances and trying out different sites by controlled diving, before choosing an appropriate one. This has been confirmed by direct observations of foraging little auks as well as by monitoring from birds using miniature TDR and GPS loggers (Harding et al. 2009; Welcker et al. 2009; Karnovsky et al. 2011; Jakubas et al. 2012). During 'sampling', little auks probably use vision to estimate site quality with respect to the abundance of the preferred food and to conditions of perception, selection and collection of C. glacialis, such as water transparency and seeking sites characterised by high $V P A v$ values.

Little auks apparently take advantage of both local water transparency and abundance of the preferred prey. Karnovsky et al. (2011) found differences in the diving behaviour of birds foraging in Hornsund, where the surface water masses are dominated by cold water carried by the Sørkapp Current, and in Kongsfjorden, where the surface waters are more influenced by the Atlantic West Spitsbergen Current. In Hornsund, vertical ascents of diving little auks were on average, $50 \%$ slower than vertical descents and birds also made a greater proportion of shallow dives. These slower ascent rates and a higher proportion of shallower dives are probably a consequence of foraging in cold Arctic-origin water where both water transparency and densities of $C$. glacialis at shallower depths are higher. In these conditions, the diving little auks are probably better able to utilise the 'silhouette effect', in which prey items are more perceptible when back-lit against the water's surface (Wilson et al. 1996; Benoit-Bird et al. 2011).

Increasing inflows of Atlantic waters into the western shelf of Spitsbergen is likely to result in the deterioration of the foraging efficiency of planktivorous seabirds through a decrease in visual prey availability. Little auks, however, are able to compensate for poorer feeding conditions by increasing their foraging effort, and taking advantage of local or seasonal high food quality and availability (Jakubas et al. 2007; Welcker et al. 2009; Kwasniewski et al. 2010; Jakubas et al. 2011). They also have some potential to shift their selected prey from crustaceans to small fish, especially in winter (Fort et al. 2010). This adaptation might help them to adjust to the less favourable environmental changes in the North Atlantic, which are now beginning to occur. However, in the long-term time perspective, little auks are able to successfully breed and rear their chicks only in highly productive, cold and transparent waters adjacent to breeding colonies, where they efficiently forage on abundant energy-rich and easily available copepods (Stempniewicz et al. 2007; Moe et al. 2009).

Acknowledgments The study was supported by grants from Polish Ministry of Science and Higher Education (1883/P01/2007/32, IPY/ 25/2007) and Norwegian Financial Mechanism (ALKEKONGE, PNRF-234-AI-1/07). We thank Dr Mateusz Ciechanowski, Jarosław Wrosz and Jan Samołyk for assistance in the field. We acknowledge the captain and the crew of the RV "Oceania" (Institute of Oceanology of Polish Academy of Sciences) for ship logistics and help in the sea. Special thanks go to Dr Martin Angel (National Oceanography Centre, Southampton, UK) for his comments of the first draft and invaluable help in English improvement. We are also grateful to Dr Adrian Zwolicki for discussion on data analyses. The study was conducted under the permission of the Governor of Svalbard.

Open Access This article is distributed under the terms of the Creative Commons Attribution License which permits any use, distribution, and reproduction in any medium, provided the original author(s) and the source are credited.

\section{References}

Ainley DG (1977) Feeding methods in seabirds: a comparison of polar and tropical nesting communities in the eastern Pacific Ocean. In: Llano GA (ed) Adaptations within Antarctic ecosystems. Smithsonian Institution, Washington, DC, pp 669-685

Aksnes DL, Giske J (1993) A theoretical model of aquatic visual feeding. Ecol Model 67:233-250

Baptist MJ, Leopold MF (2010) Prey capture success of Sandwich Terns Sterna sandvicensis varies non-linearly with water transparency. Ibis 152:815-825. doi:10.1111/j.1474-919X.2010.01054.X

Benoit-Bird KJ, Kuletz K, Heppell S, Jones N, Hoover B (2011) Active acoustic examination of the diving behavior of murres foraging on patchy prey. Mar Ecol Prog Ser 443:217-235. doi: 10.3354/meps09408 
Daase M, Vik JO, Bagøien E, Stenseth NCh, Eiane K (2007) The influence of advection on Calanus near Svalbard: statistical relations between salinity, temperature and copepod abundance. J Plankton Res 29:903-911

Day RH, Prichard AK, Nigro DA (2003) Ecological specialization and overlap of Brachyramphus murrelets in Prince William Sound, Alaska. Auk 120:680-699

De Robertis A, Ryer CH, Veloza A, Brodeur RD (2003) Differential effects of turbidity on prey consumption of piscivorous and planktivorous fish. Can J Fish Aquat Sci 60:1517-1526

Eriksson MOG (1985) Prey detectability for fish-eating birds in relation to fish density and water transparency. Ornis Scand 16:1-7

Fort J, Cherel Y, Harding AMA, Welcker J, Jakubas D, Steen H, Karnovsky N, Grémillet D (2010) Geographic and seasonal variability in the isotopic niche of little auks. Mar Ecol Prog Ser 414:293-302. doi:10.3354/meps08721

Haney JC, Stone AE (1988) Seabird foraging tactics and water clarity: are plunge divers really in the clear? Mar Ecol Prog Ser 49:1-9. doi:10.3354/meps049001

Harding AMA, Egevang C, Walkusz W, Merkel F, Blanc S, Grémillet D (2009) Estimating prey capture rates of a planktivorous seabird, the little auk (Alle alle), using diet, diving behaviour, and energy consumption. Polar Biol 32:785-796. doi:10.1007/ s00300-009-0581-x

Harding AMA, Welcker J, Steen H, Hamer KC, Kitaysky AS, Fort J, Talbot SL, Cornick LA, Karnovsky NJ, Gabrielsen GW, Grémillet D (2011) Adverse foraging conditions may impact body mass and survival of a high Arctic seabird. Oecologia. doi: 10.1007/s00442-011-1971-7

Harris R, Wiebe L, Lenz J, Skjoldal HR, Huntley M (2000) ICES zooplankton methodology manual. Academic Press, London

Henkel LA (2006) Effect of water clarity on the distribution of marine birds in nearshore waters of Monterey Bay, California. J Field Ornithol 77:151-156. doi:10.1111/j.1557-9263.2006.00035.x

Jakubas D, Wojczulanis-Jakubas K, Walkusz W (2007) Response of dovekie to changes in food availability. Waterbirds 30:421-428

Jakubas D, Głuchowska M, Wojczulanis-Jakubas K, Karnovsky NJ, Keslinka L, Kidawa D, Walkusz W, Boehnke R, Cisek M, Kwasniewski S, Stempniewicz L (2011) Foraging effort does not influence body condition and stress level in little auks. Mar Ecol Prog Ser 432:277-290. doi:10.3354/meps09082

Jakubas D, Iliszko L, Wojczulanis-Jakubas K, Stempniewicz L (2012) Foraging by little auks in the distant marginal sea ice zone during the chick-rearing period. Polar Biol 35:73-81. doi:10.1007/s00300011-1034-x

Karnovsky NJ, Kwasniewski S, Weslawski JM, Walkusz W, Beszczynska-Möller A (2003) Foraging behavior of little auks in a heterogeneous environment. Mar Ecol Prog Ser 253:289-303

Karnovsky NJ, Harding AMA, Walkusz W, Kwasniewski S, Goszczko I, Wiktor J Jr, Routti H, Bailey A, McFadden L, Brown Z, Beaugrand G, Grémillet D (2010) Foraging distributions of little auks Alle alle across the Greenland Sea: implications of present and future Arctic climate change. Mar Ecol Prog Ser 415:283-293

Karnovsky NJ, Brown ZW, Welcker J, Harding AMA, Walkusz W, Cavalcanti A, Hardin J, Kitaysky A, Gabrielsen G, Grémillet D (2011) Inter-colony comparison of diving behavior of an Arctic top predator: implications for warming in the Greenland Sea. Mar Ecol Prog Ser 440:229-240. doi:10.3354/meps0935

Konarzewski M, Taylor JRE, Gabrielsen GW (1993) Chick energy requirements and adult energy expenditures of Dovekies (Alle alle). Auk 110:603-609

Kuroki M, Kato A, Watanuki Y, Niizuma Y, Takahashi A, Naito Y (2003) Diving behavior of an epipelagically feeding alcid, the Rhinoceros Auklet (Cerorhinca monocerata). Can J Zool 81:1249-1256. doi:10.1139/z03-112
Kwasniewski S, Hop H, Falk-Petersen S, Pedersen G (2003) Distribution of Calanus species in Kongsfjorden, a glacial fjord in Svalbard. J Plankton Res 25:1-20

Kwasniewski S, Gluchowska M, Jakubas D, Wojczulanis-Jakubas K, Walkusz W, Karnovsky N, Blachowiak-Samolyk K, Cisek M, Stempniewicz L (2010) The impact of different hydrographic conditions and zooplankton communities on provisioning little auks along the west coast of Spitsbergen. Prog Oceanogr 87:72-82

Kwasniewski S, Gluchowska M, Walkusz W, Karnovsky NJ, Jakubas D, Wojczulanis-Jakubas K, Harding AMA, Goszczko I, Cisek M, Beszczynska-Moller A, Walczowski W, Weslawski JM, Stempniewicz L (2012) Interannual changes in zooplankton on the West Spitsbergen Shelf in relation to hydrography and their consequences for the diet of planktivorous seabirds. ICES J Mar Sci 69:890-901. doi:10.1093/icesjms/fss076

Lovvorn JR (2010) Modeling profitability for the smallest marine endotherms: auklets foraging within pelagic prey patches. Aquat Biol 8:203-219. doi:10.3354/ab00210

Lythgoe JN (1979) The ecology of vision. Clarendon Press, Oxford

Mann KH, Lazier JRN (2006) Dynamics of marine ecosystems: biological-physical interactions in the oceans. Blackwell Publishing, Oxford

Martin GR, Prince PA (2001) Visual fields and foraging in Procellariiform seabirds: sensory aspects of dietary segregation. Brain Behav Evol 57:33-38. doi:10.1159/000047224

Moe B, Stempniewicz L, Jakubas D, Angelier F, Chastel O, Dinessen F, Gabrielsen GW, Hanssen F, Karnovsky N, Rønning B, Welcker J, Wojczulanis-Jakubas K, Bech C (2009) Climate change and phenological responses of two seabird species breeding in the high-Arctic. Mar Ecol Prog Ser 393:235-246. doi:10.3354/ meps08222

Stempniewicz L (1990) Biomass of dovekie excreta in the vicinity of a breeding colony. Colonial Waterbirds 13:62-66

Stempniewicz L (2001) Alle alle little auk. BWP update. J. Birds West Palearctic 3:175-201

Stempniewicz L, Blachowiak-Samołyk K, Weslawski JM (2007) Impact of climate change on zooplankton communities, seabird populations and arctic terrestrial ecosystem-a scenario. DeepSea Res II 54:2934-2945

Walczowski W, Piechura J (2007) Pathways of the Greenland Sea warming. Geophys Res Lett 34:L10608. doi:10.1029/2007GL0 29974

Ward P, Zahavi A (1973) The importance of certain assemblages of birds as "information-centers" for food-finding. Ibis 115:517-534

Weimerskirch H, Bertrand S, Silva J, Marques JC, Goya E (2010) Use of social information in seabirds: compass rafts indicate the heading of food patches. PLoS ONE 5:e9928. doi:10.1371/ journal.pone.0009928

Welcker J, Harding AMA, Karnovsky NJ, Steen H, Strøm H, Gabrielsen GW (2009) Flexibility in the bimodal foraging strategy of a high Arctic alcid, the little auk Alle alle. J Avian Biol 40:388-399

Weslawski JM, Stempniewicz L, Mehlum F, Kwasniewski S (1999) Summer feeding strategy of the Little Auk Alle alle from Bjornoya, Barents Sea. Polar Biol 21:129-134

White CR, Day N, Butler PJ, Martin GR (2007) Vision and foraging in cormorants: more like herons than hawks? PLoS ONE 2:e639. doi:10.1371/journal.pone.0000639

Wilson RP, Culik BM, Peters G, Bannasch R (1996) Diving behaviour of Gentoo penguins, Pygoscelis papua; factors keeping dive profiles in shape. Mar Biol 126:153-162

Zaneveld JRV, Pegau WS (2003) Robust underwater visibility parameter. Opt Express 11:2997-3009

Zaneveld JRV, Kitchen JC, Moore CC (1994) The scattering error correction of reflecting-tube absorption meters. In: Ocean optics XII, Proc SPIE 2258:44-55. doi:10.117/12.190095 